\begin{tabular}{|c|c|}
\hline Japnal Kesmas Untika Luwuk: Public Health Journa & KESHAS \\
\hline Volume 12, Nomor 2, Desember 2021 & \\
\hline P-ISSN: 2086-3773, E-ISSN: 2620-8245 & \\
\hline Website: https://journal.fkm-untika.ac.id/index.php/phj & \\
\hline This work is licensed under a Creative Commons Attribution 4.0 International License. & $8=$ \\
\hline
\end{tabular}

\title{
PENYEBAB BALITA TIDAK IMUNISASI DASAR LENGKAP DI DESA KALUMBATAN KABUPATEN BANGGAI KEPULAUAN
}

(The Causes Of Not Complete Basic Basic Immunizations In Kalumbatan Village, Banggai

Kepulauan Regency)

\section{Lingsi Alpon', Ramli1 ${ }^{*}$, Marselina Sattu1, Derthan E.F.Polunggu1, Muhammad Syahrir ${ }^{1}$, Mirawati Tongko ${ }^{1}$}

${ }^{1}$ Fakultas Kesehatan Masyarakat Universitas Tompotika Luwuk Banggai

*Koresponden Penulis: ramli.bidullah@gmail.com

\begin{abstract}
ABSTRAK
Imunisasi merupakan pencegahan primer yang sangat efektif untuk menghindari terjangkitnya penyakit infeksi. Oleh sebab itu, angka kejadian penyakit infeksi akan menurun, kecacatan serta kematian yang ditimbulkannya pun akan berkurang. Sampai saat ini kasus yang ditemukan dilapangan ternyata masih ada ibu-ibu balita yang tidak mau membawa anaknya untuk diberikan imunisasi. Desa Kalumbatan merupakan satu-satunya Desa di Kecamatan Totikum Selatan yang belum mencapai target Universal Child Immunization (UCI). Penelitian ini bertujuan untuk memperoleh informasi penyebab ibu balita tidak memberikan imunisasi dasar pada balitanya di Desa Kalumbatan Kecamatan Totikum Selatan. Penelitian ini merupakan penelitian kualitatif dengan pendekatan fenomenologi, metode pengumpulan data dengan observasi dan wawancara mendalam (indepht interview). Informan dalam penelitian ini berjumlah 20 orang yakni ibu yang memiliki balita 0-59 bulan yang tidak lengkap imunisasi dasar balitanya, kader Posyandu dan petugas kesehatan yang didapatkan menggunakan metode pengambilan informan dengan teknik sampling menggunakan Snow Ball Sampling. Analisis data melalui tiga prosedur yaitu reduksi data, penyajian data dan penarikan kesimpulan. Hasil penelitian ini menunjukkan bahwa penyebab ibu balita tidak memberikan imunisasi dasar lengkap pada balitanya di Desa Kalumbatan ditemukan 5 informasi yakni : Takut dan trauma balitanya demam setelah diimunisasi, jarak rumah ke Posyandu yang jauh, sibuk dengan pekerjaan, tidak ada dukungan keluarga dan tidak mengetahui informasi jadwal imunisasi. Perlu adanya atau ditingkatkan promosi kesehatan kepada orang tua maupun peserta posyandu terkait peningkatan pemahaman atau pengetahuan tentang manfaat pentingnya imunisasi. Sehingga mampu meningkatkan cakupan imunisasi dasar di kabupaten Banggai Kepulauan khususnya Desa Kalumbatan Kecamatan Totikum Selatan.
\end{abstract}

\section{Kata kunci: Imunisasi dasar lengkap, dukungan keluarga, pekerjaan, balita.}

\section{ABSTRACT}

Immunization is a very effective primary prevention to avoid contracting infectious diseases. Therefore, the incidence of infectious diseases will decrease, the resulting disability and death will also decrease. Until now, the cases found in the field are still mothers of toddlers who do not want to bring their children to be given immunizations. Kalumbatan Village is the only village in South Totikum District that has not yet reached the Universal Child Immunization (UCI) target. This study aims to obtain information on the reasons why mothers of toddlers do not provide basic immunizations for their toddlers in Kalumbatan Village, South Totikum District. This research is a qualitative research with a phenomenological approach, data collection methods with observation and in-depth interviews (indepht interviews). The informants in this study were 20 people, namely 
mothers who had toddlers 0-59 months whose basic immunizations were incomplete, Posyandu cadres and health workers who were obtained using the informant retrieval method with a sampling technique using Snow Ball Sampling. Data analysis through three procedures, namely data reduction, data presentation and drawing conclusions. The results of this study indicate that the causes of mothers under five who do not provide complete basic immunization to their toddlers in Kalumbatan Village found 5 information, namely: Fear and trauma of toddlers having fever after being immunized, far from home to Posyandu, busy with work, no family support and not knowing information immunization schedule. It is necessary to have or improve health promotion to parents and posyandu participants related to increasing understanding or knowledge about the benefits of the importance of immunization. So as to increase the coverage of basic immunization in Banggai Islands district, especially Kalumbatan Village, South Totikum District.

Keywords: Complete basic immunizations, family support, work, toddlers. 


\section{PENDAHULUAN}

Infeksi yang dapat dicegah dengan imunisasi (PD3I) masih menonjol karena masih menjadi penyebab kematian pada anak. Penyakit akibat infeksi masih menjadi masalah kesehatan di negara berkembang, termasuk Indonesia. Penyakit infeksi merupakan penyakit yang tak tertahankan dan merupakan pendorong utama kematian anak. Penyakit yang tidak dapat dicegah memerlukan upaya pencegahan dan penanggulangan, salah satunya dengan imunisasi (Kemenkes, 2016). Diperkirakan di seluruh dunia pada tahun 20131 dari 5 anak atau sekitar 21,8 juta anak tidak mendapatkan imunisasi. Pemerintah mencanangkan Program imunisasi lengkap pada bayi usia 0-11 bulan, yakni : BCG, Hepatitis B, DPT-Hib, Polio, dan Campak (Kemenkes, 2016).

Diperkirakan lebih dari 109 juta balita di dunia telah disuntik pada 2010, namun "sekitar 19,3 juta balita secara keseluruhan belum tercakup oleh pemberian vaksinasi rutin (WHO, 2012). Tujuan pembangunan ekonomi (SDGS) adalah untuk menurunkan angka kematian bayi dan balita sebelum akhir tahun 2030 hingga mencapai batas 25 untuk setiap 1.000 kelahiran hidup di semua negara (SDGs, 2015).

Menurut Undang-Undang Nomor 36 Tahun 2009 tentang Kesehatan, imunisasi merupakan salah satu upaya untuk mencegah terjadinya penyakit menular yang merupakan salah satu kegiatan prioritas Kementerian Kesehatan sebagai salah satu bentuk nyata komitmen pemerintah untuk mencapai Sustainable Development Goals (SDGs) khususnya untuk menurunkan angka kematian pada anak (Kemenkes RI, 2017)

Menurut data profil kesehatan Sulawesi Tengah (2019) Capaian cakupan Imunisasi Dasar Lengkap Provinsi Sulawesi Tengah tahun 2019 mencapai 93,2\% dengan target tahunan sebesar 93\%. Hal tersebut menunjukkan bahwa cakupan IDL sudah memenuhi atau mencapai target dibanding dengan tahun 2018 yang mencapai 90,1\%. Sementara Kabupaten/Kota yang sudah mencapai terget yaitu Kabupaten Banggai Kepulauan (104,1\%), Kabupaten Banggai $(96,1 \%)$, Kabupaten Morowali $(127,7 \%)$, Kabupaten Tolitoli (97,6\%), Kabupaten Sigi (95,2\%), dan Kota Palu (97,6\%). Kabupaten/Kota ini mencapai target karena peran serta masyarakat yang tinggi di daerah ini cukup tinggi terhadap pelayanan imunisasi (Profil Kesehatan Sulteng, 2019). Berdasarkan data profil kesehatan tersebut, cakupan IDL khususnya Kabupaten Banggai Kepulauan sudah mencapai target tetapi untuk Desa Kalumbatan sendiri masih menjadi masalah yang masih perlu diperhatikan terutama pada tingkat kehadiran orang tua yang membawa anaknya untuk diimunisasi (Sulteng, 2019).

salah satu yang masih menjadi masalah kesehatan masyarakat Kalumbatan adalah masalah imunisasi dasar lengkap pada bayi yang belum mencapai target Universal Child Immunization (UCI). Permasalahan kesehatan di Desa Kalumbatan khususnya masalah imunisasi saat ini adalah balita yang tidak di berikan imunisasi dasar lengkap sehingga berdampak pada cakupan Imunisasi Dasar Lengkap (IDL) yang belum mencapai target UCI 100\%. Adapun tujuan peneltian ini untuk memperoleh informasi penyebab ibu balita tidak memberikan imunisasi dasar lengkap pada balitanya di Desa Kalumbatan Kecamatan Totikum Selatan Kabupaten Banggai Kepulauan.

\section{METODE PENELITIAN}

Jenis penelitian ini adalah kualitatif yaitu wawancara mendalam kepada ibu-ibu balita, petugas kesehatan dan kader posyandu di Desa Kalumbatan Kecamatan Totikum Selatan 
Kabupaten Banggai Kepulauan dengan pendekatan fenomenologi. Lokasi pada penelitian ini dilaksanakan di Desa Kalumbatan Kecamatan Totikum Selatan Kabupaten Banggai Kepulauan pada bulan Desember sampai Agustus Tahun 2021. Subjek penelitian ini yaitu ibu-ibu balita yang memiliki balita usia 0-59 bulan, petugas kesehatan dan kader posyandu di Desa Kalumbatan dan pengambilan subjek/informan dilakukan dengan menggunakan teknik Non Probability Sampling yaitu Snow Ball Sampling. Metode pengumpulan data yaitu dengan data primer seperti melakukan observasi, wawancara mendalam (in-dept interview), dokumentasi (foto dan video) terhadap informan terkait serta data-data lain yang diperlukan dari profil kesehatan Puskesmas dan dinas kesehatan. Analisis data menggunakan tiga tahapan prosedur yaitu reduksi data, penyajian data dan penarikan kesimpulan. Teknik keabsahan data yang digunakan dalam penelitian ini adalah menggunakan teknik triangulasi sumber data atau informasi yang dihasilkan untuk meyakinkan validitas data.

\section{HASIL}

Berikut informasi yang peneliti dapatkan pada hasil wawancara mengapa ibu-ibu balita tidak membawa balitanya ke Posyandu untuk diimunisasi ataupun kunjungan ulang pada jadwal imunisasi berikutnya karena sikap ibu yang takut efek samping dari imunisasi yang dialami balitanya seperti demam, bengkak pada paha, membiru, dan kejang sebagai berikut :

"Karena saya trauma, yang pas pertama saya bawa dia, dia disuntik dilengannya bulum dia sakit, nanti dipala palanya baru depe mata tinggi, dia ta kancing dengan dia panas, depe pala-pala bangkak baru disuru kompres dengan aer lao lao abis itu ba biru baru ba kuning pala-palanya abis itu yang ka dua kalinya langsung ta kancing dia ele panas nya dengan mata tinggi, baru beda saat panas biasa dengan dia panas abis di imunisasi, kalau ini dia mata tinggi...." (NN, WA, SD, NH, $D L, Y L, E L, R S, P N, M G, C K, S K)$.

Dari hasil wawancara diatas dapat disimpulkan bahwa penyebab ibu-ibu balita tidak membawa balitanya ke Posyandu untuk diimunisasi sesuai dengan informasi pada hasil wawancara dengan informan diatas adalah takut dan trauma balitanya panas setelah diimunisasi. Karena beberapa orang balita mengalami demam pasca disuntik vaksin dan diikuti dengan bengkak terutama pada bagian pahanya dan kejang serta trauma karena pengalaman pada anak pertamanya yang mengalami efek samping setelah diimunisasi. Hal ini menjadi salah satu alasan mengapa ibu-ibu tidak mau memberikan imunisasi dasar lengkap pada balitanya dan tidak mau lagi datang pada jadwal imunisasi berikutnya.

Dari hasil wawancara mendalam dengan informan tentang penyebab lainnya ibu balita tidak membawa balitanya untuk diberikan imunisasi dasar lengkap atau ibu-ibu balita yang tidak melakukan kunjungan ulang pada jadwal imunisasi berikutnya karena masalah jarak ke Posyandu. Berikut informasi yang peneliti dapatkan dari informan mengenai keterjangkauan tempat imunisasi atau Posyandu, dari hasil wawancara terdapat ungkapan yang sama sebagai berikut :

"Baru yang jadi alasannya juga jauh tampat kalau mo bawa dia imunisasi, baku polok dengan dia barat baru torang bajalan sampe kasana diujung. Lalu waktu masih dbawa posyandu tampat posyandu masih di kantor desa jadi dekat tapi skarang so diujung jauh baru lama sampe jam 1 biasa baru padat banyak orang jadi sa bosan ne bawa biar ne dia bagini....." (WA, NN, MG, LT, CK, $S T, D L, P N, N W, Y L)$.

Berdasarkan informasi dari hasil wawancara dengan informan diatas cenderung beralasan bahwa penyebab mereka tidak membawa balitanya untuk diimunisasi pada jadwal berikutnya yaitu jarak dari rumah ke Posyandu jauh, apalagi sebagian besar informan tinggal diatas laut yang harus melewati jembatan rusak terlebih dahulu kemudian lanjut jalan kaki ke Posyandu dan merasa kelelahan saat menggendong balitanya ke Posyandu. 
Dari informasi yang peneliti dapatkan dari informan terdapat ungkapan yang sama dan merupakan salah satu alasan ibu balita tidak membawa balitanya untuk diberikan imunisasi dasar lengkap dan kunjungan kembali pada jadwal berikutnya karena dilarang oleh suami dan orang tua. Hasil wawancara sebagai berikut :

“...baru yang kadua papanya marah karna waktu yang disuntik pahanya baha, papanya juga tidak pernah lagi suru bawa. Kalau papanya tidak marah tetap sa bawa turus bo itu demi kesehatannya anak".(SD, YL, NN, ST, WA, ID, MG, LT, ND, DL, EL).

Dari pernyataan informan diatas maka disimpulkan bahwa salah satu penyebab ibu balita tidak membawa balitanya untuk diberikan imunisasi dasar lengkap dan membawa balitanya untuk diimunisasi pada jadwal berikutnya yaitu tidak adanya dukungan dari keluarga (suami dan orang tua).

Berdasarkan hasil wawancara yang telah dilakukan didapatkan informasi dari informan yang juga menjadi alasan ibu balita tidak membawa balitanya untuk diberikan imunisasi dasar lengkap dan juga ibu balita yang tidak mau lagi membawa balitanya imunisasi pada jadwal berikutnya karena masalah jadwal imunisasi. Berikut ini ungkapan 3 orang informan utama :

"Bo biese kebanyakan du nggek tonangku ko kalau waktu imunisasi karna missa ko pemberitahuan biese, biese kite ku beke mo pulang dorang baru sa tau kalau ada imunisasi....". $(N N, N W, W A)$.

Informan dalam penelitian mengungkapkan bahwa salah satu alasan mereka tidak membawa balitanya imunisasi dan tidak kembali membawa balitanya pada jadwal berikutnya dikarenakan mereka lupa bahkan tidak mengetahui jadwal imunisasi berikutnya karena tidak ada yang mengingatkan dan informasi mengenai jadwal imunisasi berikut yang disampaikan oleh kader posyandu tidak sampai ke beberapa informan tersebut.

Selanjutnya, dari hasil wawancara mendalam yang telah dilakukan peneliti didapatkan informasi dari informan terkait alasan ibu-ibu balita tidak membawa balitanya untuk diberikan imunisasi dasar lengkap dan tidak kembali membawa balitanya pada jadwal berikutnya, terdapat ungkapan yang sama bahwa mereka sibuk dengan pekerjaan menjual ikan ke pasar dan bekerja sebagai asisten rumah tangga, hasil wawancaranya sebagai berikut:

"Biasa masih bawa ikan jadi tidak ada lagi kesempatan torang, sibuk ne banyak pekerjaan torang dirumah juga, baru tidak ada juga yang disuru mamaku sibuk juga bawa ikan " (ID, MG, LT, CK, $S T, Y L)$.

“Missa sseku na moe ie baru a sibuk nganjeme du aku ma mma kok dam” (ND, RS).

Informan dalam penelitian ini mengungkapkan bahwa alasan mereka tidak membawa balitanya ke posyandu untuk diimunisasi karena pekerjaan yang tak bisa di tinggalkan. Sehingga dapat disimpulkan bahwa sibuk dengan pekerjaan merupakan salah satu penyebab ibu-ibu balita tidak membawa balitanya untuk diberikan imunisasi dasar lengkap.

\section{PEMBAHASAN}

\section{Takut dan Trauma Balitanya Demam Setelah Diimunisasi}

Membahas tentang imunisasi tentu saja tidak dapat dipisahkan dari adanya Kejadian Ikutan Pasca Imunisasi (KIPI). Reaksi simpang yang dikenal sebagai KIPI atau, Adverse Events Following Immunization (AEFI) merupakan kejadian klinis yang diduga 
berkaitan dengan imunisasi, antara lain seperti reaksi vaksin atau efek samping, efek farmakologi, reaksi suntikan, atau kesalahan prosedur. Imunisasi dasar menurut Theophilus, (2007) yang memiliki efek samping demam pasca diberikan suntik vaksin adalah imunisasi DPT (Difteri, Pertusis dan Tetanus).

Hasil penelitian yang dilakukan oleh (Astuti et al., 2016) menyatakan bahwa kecenderungan ketidakpatuhan orang tua dalam pemberian suntikan imunisasi disebabkan oleh beberapa alasan, yaitu : adanya perasaan khawatir, dan ketakutan orang tua jika anak-anak mereka diimunisasi, mereka akan mengalami sakit panas atau demam, orang tua seringkali merasa lupa, atau tidak ada yang mengingatkan rencana jadwal pemberian imunisasi sehingga anaknya tidak mendapatkan imunisasi sesuai rencana atau jadwal.

Beberapa alasan pada hasil penelitian yang didapatkan dari ibu balita di Desa Kalumbatan tidak mau membawa anak-anak mereka untuk diberikan imunisasi dasar lengkap salah satu diantaranya, karena takut dengan efek samping setelah diimunisasi yaitu mengalami demam atau panas, kejang, dan bengkak pada bagian tubuh yang disuntik vaksin bahkan hal ini sudah menjadi trauma pada ibu yang pernah mengalami kejadian ikutan pasca anaknya diberikan imunisasi beberapa hari sehingga ibu menolak memberikan imunisasi dasar lengkap.

\section{Jarak dari Rumah Ke Posyandu Jauh}

Menurut teori Lawrence W. Green 1980, salah satu variabel atau faktor yang mempengaruhi perilaku, khususnya perilaku kesehatan adalah Faktor pendukung (Enabling Factors) diantaranya yaitu keterjangkauan tempat layanan kesehatan. Menurut Teori Lawrence Green dalam buku (Notoatmodjo, 2007), seseorang tidak mau membawa imunisasi anaknya ke Posyandu dapat disebabkan karena orang tersebut tidak tahu manfaat imunisasi bagi anaknya atau karena jarak rumah yang jauh ke Posyandu atau Puskesmas tempat imunisasi anaknya.

Sejalan dengan hasil penelitian yang dilakukan oleh Alpian Umbu Dewa, (2017) bahwa salah satu alasan orang tua tidak membawa anaknya untuk imunisasi adalah jarak yang jauh dari tempat tinggal ke tempat pelayanan imunisasi.

Dalam penelitian ini jarak terjauh dari tempat tinggal ke posyandu kurang lebih 500 Meter dan ada yang harus dijangkau melalui jembatan rusak dan jalan kaki. Informasi yang diperoleh dari beberapa informan utama bahwa salah satu yang membuat mereka tidak mau ke Posyandu untuk diimunisasi karena merasa kelelahan harus jalan kaki sambil menggendong anaknya dan ada juga yang harus ditemani oleh keluarga untuk dibantu menggendong balitanya, tetapi jika harus ke Posyandu sendiri, ibu balita memilih untuk tidak ke Posyandu karena tidak ada yang menemani jalan kaki dan membantu menggendong balitanya. hal inilah yang menjadi salah satu alasan mengapa ibu tidak membawa balitanya untuk diimunisasi.

\section{Sibuk dengan Pekerjaan}

Banyak ibu-ibu bekerja mencari nafkah, baik untuk kepentingan sendiri maupun kelurga. Faktor bekerja pun nampak berpengaruh terhadap peran ibu yang memiliki balita sebagai timbulnya suatu masalah pada ketidakaktifan ibu berkunjung ke posyandu, karena mencari nafkah untuk memenuhi kebutuhan yang belum cukup 
sehingga berdampak pada tidak adanya waktu para ibu balita untuk aktif pada kunjungan posyandu (RI, 2008)

Keterbatasan waktu yang disebabkan karena kesibukan dari orang tua khususnya ibu-ibu balita karena pekerjaan hal ini sejalan dengan penelitian Sihotang \& Rahma, (2017) bahwa keterbatasan waktu berpengaruh pada kunjungan bayi dan balita ke posyandu hal ini dikarenakan kesibukan yang dimiliki oleh orang tua yang memiliki bayi dan balita serta tidak ada waktu ibu untuk mencari informasi karena kesibukan mereka dalam bekerja setiap harinya.

Pekerjaan merupakan satu keharusan yang dilakukan sebagian besar ibu-ibu di Desa Kalumbatan apalagi yang suaminya bekerja sebagai seorang Nelayan dan ibuibunya yang harus membawa hasil dari laut seperti menjual ikan ke pasar sejak pagi hingga menjelang siang bahkan ibu-ibu yang harus bekerja sebagai Asisten Rumah Tangga hingga tidak memiliki kesempatan atau waktu untuk membawa balitanya ke Posyandu untuk diimunisasi. Sesuai dengan hasil observasi yang telah dilakukan peneliti di Desa Kalumbatan bahwa ibu-ibu yang bekerja menjual ikan ke Pasar berangkat dari pagi hingga siang hari menunggu sampai ikan habis terjual lalu kembali ke rumah dan itu sudah menjadi pekerjaan setiap harinya, kalaupun suami mereka tidak memancing ke laut tetapi ibu-ibu tersebut tetap ke pasar membawa ikan yang telah dibeli dari penjual lainnya dan dijual kembali. Sama hal seperti ibu balita yang bekerja sebagai asisten rumah tangga, mereka hanya mendapat penghasilan dari bekerja sebagai ART, jika tidak bekerja maka tidak akan mendapatkan penghasilan karena mereka harus menghidupi keluarga melalui pekerjaan tersebut dan saat bekerja informan terpaksa harus menitipkan balitanya pada orang lain.

\section{Tidak Ada Dukungan Keluarga}

Menurut teori yang dijelaskan oleh Wetle (1997) dalam Lestari et al., (2011) bahwa keberadaan anggota keluarga, dan dukungan yang diberikan memilikii peranan penting dalam mencegah atau menunda seseorang yang menderita penyakit kronis untuk pergi berobat. Selain itu, dukungan yang diberikan dapat berupa dukungan emosional, dukungan penghargaan, informasional dan instrumental yang mampu mempengaruhi minat seseorang dalam berperilaku (Friedman, 2010).

Penelitian ini sejalan dengan penelitian Sihotang \& Rahma, (2017) bahwa dalam penelitiannya didapat tidak adanya dukungan keluarga juga berpengaruh terhadap kunjungan bayi dan balita hadir ke Posyandu. Jika tidak adanya dukungan keluarga untuk membawa anaknya ke Posyandu, maka ibu tidak membawa anaknya untuk datang ke Posyandu setiap bulannya.

Tidak ada dukungan keluarga menjadi salah satu penyebab mengapa ibu balita tidak membawa balitanya untuk diimunisasi dasar di Desa Kalumbatan, seperti suami bahkan orang tua pun telah melarang informan untuk membawa balitanya setelah Kejadian Ikutan Pasca Imunisasi terjadi pada balitanya sehingga informan pun tidak lagi membawa balitanya untuk diimunisasi. Bahkan ada yang suami mereka tidak peduli dan tidak mengurusi masalah itu. Menurut peneliti salah satu hal yang perlu diperhatikan adalah pendekatan serta penyuluhan tentang pentingnya imunisasi seharusnya tidak hanya disampaikan kepada ibu-ibu saja tetapi harus dilakukan pula pendekatan kepada orang yang berpengaruh di dalam lingkungan keluarga seperti suami dan orang tua, 
sebab salah satu yang menjadi alasan mengapa ibu-ibu tidak mau membawa balitanya untuk diimunisasi karena tidak ada dukungan dari keluarga. Hal ini disebabkan karena kurangnya pemahaman di dalam keluarga tentang pentingnya imunisasi sehingga suami maupun orang tua menganggap imunisasi pada balitanya bukan satu hal yang penting dan wajib untuk dilakukan. Salah satu kasus yang ditemukan peneliti pada saat wawancara ada informan yang mengatakan bahwa mereka masih ingin membawa balitanya untuk imunisasi tetapi takut karena telah dilarang oleh suaminya agar tidak lagi membawa anaknya untuk diimunisasi dan mereka menganggap imunisasi hanya membuat anaknya sakit.

\section{Tidak Mengetahui Informasi Jadwal Imunisasi}

Menurut Notoatmodjo, (2005) kepatuhan berpengaruh terhadap kesadaran informan untuk membawa anaknya imunisasi. Ibu yang tidak bersedia untuk membawa imunisasi bayinya dapat disebabkan karena belum memahami secara baik, benar dan mendalam mengenai imunisasi dasar. Selain itu juga disebabkan karena kurangnya perhatian terhadap jadwal imunisasi. Kesadaran yang kurang akan mempengaruhi ibu dalam memperoleh informasi mengenai pemberian imunisasi.

Pada penelitian yang dilakukan oleh Fitriani, (2017) bahwa sebagian besar responden tidak tepat dalam memberikan imunisasi dasar kepada bayinya disebabkan karena kesibukan orang tua atau faktor lupa untuk membawa anak imunisasi sesuai jadwal. Hasil penelitian yang dilakukan oleh Sihotang \& Rahma, (2017) bahwa informasi posyandu atau lokasi posyandu mempengaruhi ibu untuk membawa anaknya ke Posyandu karena banyak dari mereka yang tidak tau kapan jadwal Posyandu di tempat tinggal mereka.

pada penelitian ini bahwa mereka tidak membawa balitanya untuk diimunsasi dikarenakan beberapa informan tidak mendapatkan informasi tentang jadwal pelaksanaan imunisasi berikutnya serta perubahan jadwal yang tiba-tiba disampaikan dikarenakan petugas kesehatan yang berhalangan hadir. Alasan tersebut juga diperkuat oleh pernyataan dari kader posyandu bahwa mereka selalu menyampaikan informasi tentang jadwal pelaksanaan imunisasi tetapi tidak secara menyeluruh dan langsung kepada ibu balitanya. Kader posyandu hanya menyampaikan mengenai informasi jadwal hanya kepada ibu-ibu yang rutin ke Posyandu kemudian menitip pesan untuk disampaikan kepada ibu-ibu balita lainnya yang jarang ke Posyandu membawa balitanya untuk diimunisasi, tetapi ternyata masih ada ibu-ibu balita yang peneliti temukan tidak mengetahui jadwal pelaksanaan imunisasi. Mereka akan mengetahuinya ketika telah melihat ibu-ibu balita lainnya jalan ke Posyandu untuk imunisasi kemudian diketahui bahwa ternya ada pelaksanaan jadwal imunisasi.

\section{KESIMPULAN DAN SARAN}

Berdasarkan hasil penelitian sesuai dengan tujuan penelitian dapat disimpulkan bahwa penyebab ibu balita tidak membawa balitanya untuk diberikan imunisasi di Desa Kalumbatan sebagai berikut :

Takut dan Trauma Balitanya Demam Setelah Diimunisasi, informan mengaku takut setelah balitanya diberikan imunisasi mengalami demam tinggi, kejang, bengkak dan kebiruan pada bagian tubuh yang disuntik vaksin dan trauma pengalaman pada anak pertama yang mengalami KIPI, sehingga tidak mau lagi membawa balitanya untuk diberikan imunisasi berikutnya. Jarak dari Rumah Ke Posyandu Jauh, informan 
mengeluh tempat posyandu jauh dan merasa lelah membawa balitanya karena harus menggendong balitanya sendiri dan harus jalan kaki sampai ke Posyandu. Sibuk Dengan Pekerjaan, informan tidak memiliki kesempatan untuk membawa balitanya untuk diimunisasi karena harus bekerja membawa ikan ke pasar dari pagi hingga siang hari, ada yang masih kerja sebagai asisten rumah tangga, dan ada yang sibuk karena mengurus pekerjaan rumah tangga. Tidak Ada Dukungan Keluarga, informan mengaku dilarang oleh suami membawa balitanya ke posyandu karena setelah diimunisasi balitanya demam. Selain itu juga informan mengaku malas karena tidak ada pula dukungan dari pihak keluarga. Tidak Mengetahui Informasi Jadwal Imunisasi, informan mengaku tidak mengetahui jika sudah tiba jadwal untuk imunisasi karena tidak ada informasi disampaikan kepada mereka. Informan akan mengetahui jika ada jadwal pelaksanaan imunisasi, ketika melihat ibu-ibu balita lainnya pergi atau pulang dari Posyandu kemudian mengetahui ternyata ada jadwal imunisasi hari tersebut.

Adapun saran dalam penelitian ini yaitu perlu ditingkatkan promosi kesehatan bukan hanya ke peserta posyandu tetapi lebih ke pendekatan keluarga seperti suami dan orang tua tentang pentingnya imunisasi, penyampaian informasi secara menyeluruh mengenai jadwal imunisasi seperti penyampaian melalui rumah ibadah, konsultasi ke dokter ketika balita mengalami KIPI seperti efek samping, diadakan tambahan posyandu minimal 2 buah dan kendaraan umum seperti mobil di Desa Kalumbatan dan perbaikan akses jembatan penghubung dari rumah warga.

\section{UCAPAN TERIMA KASIH}

Terima kasih peneliti ucapkan kepada semua pihak yang sudah terlibat dalam penelitian ini yang tidak sempat disebutkan satu-persatu, terkhusus kepada pemerintah Desa Kalumbatan Kecamatan Totikum Selatan yang dijadikan sebagai lokasi penelitian.

\section{DAFTAR PUSTAKA}

Alpian Umbu Dewa. (2017). Alasan Orang Tua Tidak Membawa Anaknya Untuk Imunisasi. Skripsi. Keperawatan Universitas Airlangga. http://repository.unair.ac.id/77554/

Astuti, S. J., Yudiernawati, A., \& Maemunah, N. (2016). Hubungan Tingkat Kepatuhan Orang Tua Terhadap Pemberian Kelengkapan Imunisasi Dasar Pada Bayi Di Puskesmas Batu Kota Batu. 1(1), 181-189.

Fitriani, E. (2017). Faktor Yang Mempengaruhi Ketepatan Pemberian Imunisasi Dasar Di Wilayah Kerja Puskesmas Perawatan Tanjung Seloka Kabupaten Kota Baru Tahun 2017. Skripsi. Jurusan Kebidanan, Poltekes Kemenkes Yogyakarta.

Friedman M. Marliyan. (2010). Buku Ajar Keperawatan : Riset, Teori dan Praktik Edisi ke5. Jakarta : EGC.

Kemenkes, R. I. (2016). Pusat Data Dan Informasi: Status Imunisasi Di Indonesia. Jakarta: Kemenkes RI.

Kemenkes RI. (2017). Peraturan Menteri Kesehatan Republik Indonesia Nomor 12 Tahun 2017 Tentang Penyelenggaraan Imunisasi. Jakarta: Kemenkes RI.

Lestari, P., Hadisaputro, S., \& Pranarka, K. (2011). Beberapa Faktor yang Berperan Terhadap Keaktifan Kunjungan Lansia ke Posyandu Studi Kasus di Desa Tamantirto Kecamatan Kasihan Kabupaten Bantul Propinsi DIY. Jurnal Media Medika Indonesia, 
45(5). http://ejournal.undip.ac.id

Notoatmodjo, S. (2005). Promosi Kesehatan: Teori dan Aplikasi. Jakarta: PT. Rineka Cipta.

Notoatmodjo, S. (2007). Konsep perilaku dan perilaku kesehatan. In Dalam: Promosi Kesehatan dan Ilmu Perilaku. Jakarta : PT. Rineka Cipta.

RI, D. (2008). Pelayanan sistem Kesehatan (pp. 1-327).

SDGs. (2015). Sustainable Development Knowledge Platform. Goal 3.

Sihotang, H. M., \& Rahma, N. (2017). Faktor Penyebab Penurunan Kunjungan Bayi Di Posyandu Puskesmas Langsat Pekanbaru Tahun 2016. Jurnal Endurance, 2(2), 173174. https://doi.org/10.22216/jen.v2i2.1803

Sulteng, D. S. (2019). Profil Kesehatan (pp. 1-222). Dinas Kesehatan Sulawesi Tengah. Theophilus. (2007). Imunisasi Sehat. Jakarta : Trans Info Media. 